\title{
Space/place matters
}

\section{WHERE ARE WE COMING FROM?}

$\mathrm{T}$

his special issue of Multilingual Margins on the theme of "Space/ place matters" has its origin in a doctoral summer school organised in December 2016 by the Department of Linguistics and the Centre for Multilingualism and Diversities Research at the University of the Western Cape as part of a collaboration with the University of Oslo and three other South African universities - Stellenbosch University, University of Cape Town and University of the Witwatersrand - and financed by Research Council of Norway's programme International Partnerships for Excellent Education, Research and Innovation (INTPART). Doctoral students based in Norway and South Africa attended the summer school, presented their research projects, and were encouraged to submit an article to Multilingual Margins. This was with a view to training budding scholars to deal with the peer-review process of academic publishing. This special issue is the material outcome of this process and includes three articles that have a common interest in unpicking the complex relationship between language and space/place.

\section{SPACE/PLACE}

The notions of space/place have always played an important role in sociolinguistic inquiry. Understood as either geographical locale or social class position, space was employed in early variationist studies as a pre-existing independent variable which can explain patterns of language variability. Partly as a result of the socalled post-structuralist turn in the social sciences, however, sociolinguists have begun to emphasise the dynamic and discursive nature of space. For example, Jan Blommaert writes that "[s]pace can be filled with all kinds of social, cultural, epistemic, and affective attributes. It then becomes 'place', a particular space on which senses of belonging, property rights, and authority can be projected" (2005: 222).

The increased sociolinguistic interest in the meanings, values and political tensions of spaces/places manifests itself perhaps most clearly in the burgeoning scholarship of Linguistic Landscape (LL), a subfield which aims to capture "[t]he language of public road signs, advertising billboards, street names, commercial shop signs, and public signs on government buildings" (Landry and Bourhis 1997: 25; see also Shohamy and Gorter 2009; Jaworski and Thurlow 2010; Zabrodskaja and Milani 2014 for overviews of the development of LL as a field of inquiry). LL research relies on a plethora of methodological techniques, from quantitative procedures such as counting how many times different languages appear on signs in multilingual cities (e.g. Shohamy 2006; Backhaus 2007) to more qualitative approaches which attempt to capture the interaction between the verbal and the visual in public signage (e.g. the contributions to Jaworski and Thurlow 2010), and, to long-standing ethnographies of how people perceive and make sense of public signage in their daily lives (e.g. Malinowski 2009; 2010; Leeman and Modan 2009; Todd Garvin 2010; Stroud and Jegels 2014; Peck and Stroud 2015).

Focusing rather less on the built environment than on the affordances of 
the realm of the "digital", space/place have also been a key object of investigation in research about language and "new media". For example, Brian King draws upon the sociologically inspired framework of "atmospheric analysis" (Green et al. 2010; see also Baudrillard 1996) in order to shed light on the discursive intersections of sexuality and space in an online chat. Atmospheric analysis is an approach that views the dialectic relationship between the materiality of space "as concrete physical environments" (Green et al. 2010: 11), on the one hand, and place, on the other, as "a discursive field that provides ... [a] symbolic backdrop against which actors build and negotiate erotic meanings and practices" (Green et al. 2010: 8; see also Stroud and Mpendukana 2009 for a similar conceptualization of multilingualism in public spaces). On the basis of this theoretical scaffolding, King convincingly demonstrates how the website architecture, "that is both visible (the chat interface) and metaphorical (the [chat] 'room')" (2012: 110), influences the participants in an online chat to jointly construct an eroticised place through explicit narrations of bodies and sexual practices. Although this "erotic oasis" (King 2012: 112) is not unanimously accepted by all interlocutors, King points out that even the conversational dis-alignments produced by one of the participants and the concomitant contestations of the sexualised topic of the chat fuel the eroticised atmosphere of the virtual room. This is because any act of prohibition or resistance tends to reproduce those very categories that the defiance seeks to disallow, transcend or critique (see also Foucault 1978; Butler 1997).

Though underpinned by a similar interest in understading the role of language and social processes, variationist sociolinguistics, linguistic landscape scholarship and research on language and digital media constitute three bodies of scholarship that have beeb quite separate from each other. In contrast, the aim of this special issue is to bring together three articles that individually contribute to each of these approaches to the study of space, but collectively engage on some level with the ways in which the margins can offer a useful entry point for sociolinguistic inquiry. It is to such a perspective that we will now turn.

\section{MARGINALLY SPEAKING}

None of the contributors to this special issue overtly draw upon the notion of the margins. However, we believe that a "marginal perspective" is what runs across the three articles. One of us has argued elsewhere that the margins can be an important heuristics through which to capture sociolinguistic processes of boundary making as well as the creation of power inequalities. This is because

Marginality inherently points us towards what at a particular moment is (viewed as) non-central and non-dominant. Most importantly, marginality is not reducible to statistically measurable structural conditions (e.g., income level). Nor is it a straightforward and stable discursive position. Rather, what counts as marginal is in constant flux and is the object of continual negotiations and contestation; it is intersectionally complex and contextually relational. (Milani 2014: 175)

Overall, as a spatial point of a reference, a perspective from the margins always entails a queer gaze, an act of looking askew, of being both unsettled and 
potentially unsettling. Highlighting the act of troubling from the margins is not only in line with a critical sociolinguistic imperative to question unequal power relations and ideological biases but is also in line with current discussions about the importance of including affect into the analytical repertoire of sociolinguistic inquiry (see McElhinny 2010; Milani 2015; Peck and Stroud 2015; Bucholtz and Hall 2016).

A marginal perspective clearly emerges in Yolandi Ribbens-Klein's detailed linguistic analysis of rhotic variation in Afrikaans spoken in a small town in the Western Cape. While racist grand narratives of apartheid sought to whitewash Afrikaans enregistering (Agha 2005) it as the language of white European settler colonialists of Dutch heritage, the article takes the perspectives of the actual majority of Afrikaans speakers, namely the so-called "Coloured" population, which, numbers of speakers notwithstanding, is consistently pushed to the margins of who the Afrikaans "speech community" actually includes. RibbensKlein illustrates how variants of $(r)$ - what is considered "standard" uvular-r and "non-standard" alveolar " $r$ " - coexist in a Coloured speaker's linguistic repertoire, and are strategically deployed to create meanings of "extreme locality", that is, "a space that binds participants together around a common understanding of the local bric and brac of events and reference points that they share, and the people they know" (Williams and Stroud 2010: 40). Considering the speech production of someone who has historically been considered a "marginal speaker" of Afrikaans allowed the researcher to unveil an interesting pattern of "acts of identity" (Le Page and Tabouret-Keller 1986): uvular-r is deployed by the speaker in question in order to index in-group membership; alveolar-r instead is employed to indicate those from whom he wants to distance himself and be distinguished.

Linguistic negotiations of identity are also brought under the spotlight by Maria Antonina Obojska, this time though in the context of an online discussion between Ana, a Polish young woman in Norway, and her followers. Here we can see how long-standing language ideologies of one nation one language frame the stances taken by the followers against the young woman's usage of Norwegian instead of Polish in conversation with other Polish speakers in Norway. Such monoglot ideologies are used to marginalise Ana through affective acts of shaming. Such a discursive and affective marginalisation however does not remain unchallenged by Ana, who speaks back to essentialist views of the language/nation nexus, arguing for "a flexible multilingual identity for herself and other Polish migrant adolescents in Norway" (Obojska, this volume). The analysis in this article offers another empirical case in point of the dynamic nature of the media as discursive sites of language ideological brokerage. As Sally Johnson and Astrid Ensslin put it

the media mirror, and hence implicitly promote, a dynamic set of ideological frameworks. Crucially, however, these are not necessarily restricted to dominant discourses but also enable marginal agencies to surface, and potentially alter, previous hierarchical relations (2007: 12 emphasis in original).

In the specific case of the online platform under investigation in Obojska's paper, digital spaces play an important role of ideological brokers between diasporic communities and the "homeland".

The final article of this special issue also investigates forms of ideological 
brokerage, but shifts gears from online space to the built environment. Quite paradoxically, the geographical centre of South Africa's largest city, the Central Business District (CBD) in Johannesburg, was for many years one of the most marginalised and stigmatised urban areas in the world. This was partly the result of an increase in crime in the area and concomitant relocation of financial institutions to the wealthier Northern suburbs of the city. More recently, however, a number of private developers have invested large amounts of capital with a view to "redeveloping" the CBD. With the help of an important but somewhat neglected work on the language of architecture, Baro problematises discourses of urban development in contemporary South Africa. While we might be tempted to unconditionally support attempts to counter the marginalisation of the CBD over the last twenty years and reposition it as the "centre" of the city, the way in which such developments are pursued are not without problems. Discourses of cleanliness and safety pay lip service to white-middle class sensibilities and ultimately feed into processes that ultimately lead to the expulsion and relocation of poor black constituencies. Under an apparently laudable surface of "regeneration", urban development ends up reproducing very problematic racial hierarchies and oppression.

Differences of approaches notwithstanding, the articles in this special issue illustrate the very different ways in which space/place can be analysed through linguistic analysis. Whether through careful attention to language variation, discourse analytical focus on identity, or a semiotic gaze on urban development, the articles collectively illustrate that space/place matters for the negotiation and construction of identity and power.
They also skilfully show some fragments of the dynamics of the margins and the marginal. But this is by no means an accomplished project, and we hope more scholarship will engage critically with a heuristics of the margins.

\section{REFERENCES}

Agha, Asif. 2005. Voice, footing, enregisterment. Journal of Linguistic Anthropology 15(1): 38-59.

Backhaus, Peter. 2007. Linguistic Landscapes. A Comparative Study of Urban Multilingualism in Tokyo. Clevedon, UK: Multilingual Matters.

Baudrillard, Jean. 1996. The System of Objects. London: Verso.

Blommaert, Jan. 2005. Discourse: A Critical Introduction. Cambridge: Cambridge University Press.

Bucholtz, Mary and Kira Hall. 2016. Embodied sociolinguistics. In Nikolas Coupland (ed). Sociolinguistics: Theoretical Debates. Cambridge: Cambridge University Press. 173-197.

Foucault, Michel. 1978. The Will to Knowledge: The History of Sexuality Volume 1. London: Penguin.

Green, Adam Isaiah, Follert, Mike, Osterlund, Kathy and Jami Paquin. 2010. Space, place and sexual sociality: Towards an 'atmospheric analysis.' Gender, Work and Organization 17(1): 7-27.

Jaworski, Adam and Crispin Thurlow (eds). 2010. Semiotic Landscapes: Language, Image, Space. London: Continuum.

Johnson, Sally and Astrid Ensslin. 2007. Language in the media: Theory and practice. In Sally Johnson and Astrid Ensslin (eds) Language in the Media: Representations, Identities, Ideologies. London: Continuum. 3-23.

King, Brian W. 2011. Language, sexuality and place: The view from cyberspace. Gender and Language 5(1): 1-30.

King, Brian W. 2012. Location, lore and language: An erotic triangle. Journal of Language and Sexuality 1(1): 106-125. 
Landry, Rodrigue and Richard W. Bourhis. 1997. Linguistic landscape and etholinguistic vitality. Journal of Language and Social Psychology 16(1): 23-49.

Le Page, R. B. and Andrée Tabouret-Keller. 1986. Acts of Identity. Cambridge: Cambridge University Press.

Leeman, Jennifer and Gabriella Modan. 2009. Commodified language in Chinatown: A contextualized approach to linguistic landscape. Journal of Sociolinguistics 13(3): 332-362.

Malinowski, David. 2009. Authorship in the linguistic landscape: A multimodalperformative view. In Elana Shohamy and Durk Gorter (eds). Linguistic Landscape: Expanding the Scenery. New York: Routledge. 107-125.

McElhinny, Bonnie. 2010. The audacity of affect: Gender, race, and history in linguistic accounts of legitimacy and belonging. Annual Review of Anthropology 39: 309-328.

Milani, Tommaso M. 2015. Language and citizenship: Broadening the agenda. Journal of Language and Politics 14(3): 319-334.

Milani, Tommaso M. 2014. Marginally speaking. Multilingual Margins 1(1): 9-20.

Peck, Amiena and Christopher Stroud. 2015. Skinscapes. Linguistic Landscape 1(1-2): 133-151.

Shohamy, Elana and Durk Gorter (eds). 2009. Linguistic Landscape: Expanding the Scenery. New York and London: Routledge.

Stroud, Christopher and Dmitri Jegels. 2014. Semiotic landscapes and mobile narrations of place: Performing the local. International Journal of the Sociology of Language 228: 179-199.
Stroud, Christopher and Sibonile Mpendukana. 2009. Towards a material ethnography of linguistic landscape: Multilingualism, mobility and space in a South African township. Journal of Sociolinguistics 13(3): 363-386.

Todd Garvin, Rebecca. 2010. Responses to the linguistic landscape in Memphis, Tennessee: An urban space in transition. In Elana Shohamy, Eliezer Ben-Rafael and Monica Barni (eds). Linguistic Landscape in the City. Bristol: Multilingual Matters. 252-271.

Williams, Quentin E. and Christopher Stroud. 2010. Performing rap ciphas in late-modern Cape Town: extreme locality and multilingual citizenship. Afrika Focus 23(2): 39-59.

Zabrodskaja, Anastassja and Tommaso M. Milani. 2014. Introduction - Signs in context: Multilingual and multimodal texts in semiotic space. International Journal of the Sociology of Language 228: $1-16$.

\section{Tommaso M. Milani}

University of Gothenburg and University of the Witwatersrand, Johannesburg

\section{Quentin Williams}

University of the Western Cape

\section{Christopher Stroud}

University of the Western Cape and Stockholm University 